\title{
Aodh Mac Aingil (Hugo Cavellus, 1571-1626) on Doubt, Evidence and Certitude
}

Michael Dunne

\begin{abstract}
When John Duns Scotus died at the young age of 42, seven centuries ago in 1308, he did not leave behind a completed body of work which would present his mature philosophical thought. Thus, the followers of Scotus were faced with the challenging task of interpreting the texts of the Subtle Docotr. Since Scotism became one of the most important schools of thought by the early modern period, the synthesis elaborated by the most famous of the commentators on Scotus's philosophy Hugo Cavellus (1571-1626), Irish Franciscan and Archbishop of Armagh is of capital importance. Cavellus dedicated a considerable part of his commentary on the De Anima of Duns Scotus to the problems relating to the theory of the knowledge. Because of Cavellus's central importance in seventeenth-century Scotism, his writings on doubt, evidence and certitude are noteworthy in terms of developments in modern thought .
\end{abstract}

Hugo Cavellus ${ }^{1}$ was born at Downpatrick, County Down, in 1571. His name as transliterated into English became Hugh MacCaghwell (or 'Caughwell') but he was also known as Aodh Mac Aingil. He entered the Franciscan order at Salamanca in 1603 or at the beginning of 1604, at the age of 33. At Salamanca he would have encountered important theologians such as Andrés de la Vega, Alfonso de Castro and Juan Lobera, who had taken part in the Council of Trent. Among his teachers in philosophy and theology were Francisco de Herrera and Juan de Ovando, who are among the best known Spanish Scotists of the seventeenth century. They would not have had much difficulty encouraging Cavellus to study Scotism, since it was believed by many, and especially the Irish friars, that the birthplace of John Duns Scotus (ca. 1266-1308) was Downpatrick (lat.: Dunensis), the same as Cavellus. Thus, it should be remembered that in editing and publishing the works of Duns Scotus, Irish Franciscans such as McCaughwell, Wadding and Hickey were promoting the glory of their order and the honour of Ireland at a time when it seemed to them that the survival of the nation was in doubt. For McCaughwell in particular Duns Scotus was one of his own people from Down. When he published his edition of the Sentences in 1620, the title page gave the name of the editor as Hugo Cavellus Hibernus Dunensis.

In June 1607 Hugo Cavellus was among the founders of the College of Saint Anthony, the college of the Irish Franciscans at Louvain, where he was rector for many years. Here he taught theology for fourteen years, handing on to his many students an enthusiastic and lasting admiration for Duns Scotus and his doctrine; these then carried Scotism to many parts of Europe. Indeed, the majority of the exponents of Scotism in the seventeenth century, quoted in their works from the Vita Scoti and the Apologia of Hugo Cavellus.

In July 1623 Cavellus arrived in Rome where he taught theology at the convent of Aracoeli. Having become professor emeritus, he was then definitor generalis and finally in

\footnotetext{
${ }^{1}$ A useful (if somewhat brief) source on Cavellus' life is the entry in the Oxford Dictionary of National Biography written by T. Clavin. The reader should note that our author is commonly known by three names, Hugh MacCaghwell, Hugo Cavellus, and Aodh Mac Aingil. The first is the anglicised version of his birth name Aodh Mac Cathmhaoil, the second the latinised version which he used in his published Latin works, and finally the name by which he is best known among Irish scholars, 'Mac Aingil', literally 'the son of an angel'. A more extensive examination of his life is to be found in C. Giblin, "Hugh McCaghwell, O.F.M., Archbishop of Armagh (+1626): Aspects of his Life"; originally published in Seanchas Ard Mhaca, xi, (1983-5), 259-90; reprinted in Dún Mbuire Killiney 1945-95. Léann agus Seanchas. Edited by Benignus Millett and Anthony Lynch. The Lilliput Press: Dublin 1995: pp. 63-94.

(C) - Michael Dunne, 'Aodh Mac Aingil (Hugh Cavellus, 1571-1626) on Doubt, Evidence and Certitude', in Maynooth Philosophical Papers, Issue 5 (2008), ed. by Simon Nolan (Maynooth: Department of Philosophy, National University of Ireland, Maynooth, 2009), pp. 1-8.
} 
1626, by the decision of Pope Urban VIII, he became Archbishop of Armagh and Primate of All Ireland. Cavellus died six months after being consecrated bishop and before being able to return to Ireland. He is buried in the College of St Isidore's, ${ }^{2}$ near to Luke Wadding and Antony Hickey.

Duns Scotus is known as the Doctor Subtilis and for good reason since he is one of the most difficult medieval authors to master. Not only that but the transmission of his writings present more than the usual problems of mistakes due to copying, etc. Like Richard FitzRalph (1300-60) a generation later (an Irishman but no friend of the Franciscans), Duns Scotus' approach to his writings seems to have been one of continual revision of a work in progress. As the editors of the 2006 edition of the Quaestiones de Anima write:

It is a striking fact that John Duns Scotus never achieved what in medieval terms was called an edition of any of his works ... Scotus' writings rather survived his death in multiple stages of revision; as he moved from one teaching assignment to another he typically continued to rework his expression, transfer materials from one work into another, rearrange parts of the text and arguments, devise new or extra arguments perhaps meant to be interpolated into a final version and which were written in the margins of surviving manuscripts, etc. ${ }^{3}$

His subtlety consists in a microanalysis of arguments, the listing of authorities for and against, the adoption of provisional positions and conclusions deferred. Scotus's early death from plague (he was roughly 43 years of age) in the middle of a very successful academic career, which had seen him lecturing at Cambridge, Oxford and Paris, his papers were put together in a somewhat haphazard fashion by his companions and this included notes for revision but also passages which Scotus had himself deleted.

McCaughwell had to make editorial decisions and this involved cutting through a Gordian knot of textual incongruities and so deleting, adding, selecting. The result, together with the work of Hickey and Wadding was the edition of the Opera Omnia of Duns Scotus which became the textus vulgatus and which still nearly 400 years later is the only complete edition available, although admittedly given the pace at which recent critical editions are appearing this may not be the case for much longer. Indeed, only last year a modern edition came out of the Quaestiones De Anima. ${ }^{4}$

But Cavellus' aims went beyond mere editing. He realised that the thought of Scotus is one of the most difficult or subtle of the main scholastic thinkers and so he provided commentaries where the Scotist tradition was represented and expounded. As Martin McNamara puts it:

He went to great pains, especially in his edition of Opus Oxoniense, to help the student to understand Scotus more easily. Much of what he did in this respect deserves the highest commendation, and must have caused him very many hours of exacting work. Before each Quaestio he cites the places in which other theologians treated of the same subject: at the beginning of the Quaestiones and often in the margins he referred the reader to those places in which Scotus dealt with a matter of a similar kind; he divided up the text and inserted summaries in italics of the matter immediately following; he had the scriptural references cited

\footnotetext{
2 'In hoc collegio': the reference is to the Irish College of S. Isidoro dei Frati Minori, at Rome, (via degli Artisti, n. 41).

${ }^{3}$ B. Ioannis Duns Scoti, Quaestiones super Secundum et Tertium De anima. Edd. C. Bazán, K. Emery, R. Green, T. Noone, R. Plevano, A. Traver. Opera Philosophica V. Washington, 2006; p. 96*.

${ }^{4}$ B. Ioannis Duns Scoti, Quaestiones super Secundum et Tertium De anima. Edd. C. Bazán, K. Emery, R. Green, T. Noone, R. Plevano, A. Traver. Opera Philosophica V. Washington, 2006. The judgement of the editors on the work of Cavellus and Wadding is rather negative: 'The result of the editors' procedures is probably the most contaminated redaction of the Quaestiones De anima in the whole textual tradition' p. 84*.
} 
by Scotus printed in a type different from that in the text; he complied exhaustive indexes of matters of note, of scriptural references, of the distinctions, and of the principal controversies treated of by Scotus. ${ }^{5}$

Again to quote Mauritius de Portu: movit enim nos, et Doctoris Scoti conterranei mei singularis benevolentia, et eius doctrina, cujus lacte ab incunabulis sum nutritus, amor non mediocris. ${ }^{6}$ In particular Cavellus transmitted the thoughts of the great writers from the previous generation in the sixteenth century. Since he had studied at Salamanca he was imbued in that tradition and brought it with him to his teaching and writing. As a result he is more than an exponent of Duns Scotus' thought. The Thomist tradition as mediated through Suarez also is treated by him with respect. Underneath all of this structure is the personal thought of an acute philosopher and theologian who has been taken somewhat for granted and yet is there at the elbow of those who read Scotus in the centuries which followed.

\section{The Quaestiones Scoti De Anima:}

The theme of certitude in dealt with by Cavellus in his supplement to the Quaestiones Scoti De Anima. My attention was directed to this through reading an article by Cathaldus Giblin who repeated the view of a $19^{\text {th }}$ century author to the effect that there were ideas in Cavellus which anticipated Descartes:

An authoritative study of McCaghwell as a theologian has yet to be done and there is at least one aspect of his writings as a philosopher which would be interesting to investigate more fully. I refer to his alleged influence on Descartes. ${ }^{7}$ In McCaghwell's edition of the De anima of Duns Scotus which came from the printers in 1625 there is to be found a treatise by McCaghwell dealing with psychology and especially with ideology. In the chapter of evidence (De Evidentia) in this work it has been stated that some of the ideas expressed by Descartes, especially as regards dreams, sleep and the certitude of the senses. ${ }^{8}$

\footnotetext{
${ }^{5}$ Máirtín Mac Conmara, "Mac Aingil agus an Scotachas Éireannach”, in An Léann Eaglasta in Eireann $1200-$ 1900, (Dublin 1988). pp. 61-101; p. 82: Thóg Mac Aingil de dhua air féin téacs áirithe de Scotus a bhí á chur in eagar aige ar leagan amach i slí go mbeadh ord an téacs féin mar chabhair don léitheoir agus don mhac léinn. Rinne sé é sin ach go háirithe leis an eagrán de na Sententiae san Opus Oxoniense. Roimh gach Quaestio tugann sé na háiteanna ina ndéanann diagairí eile cur síos ar an ábhar céanna. Ag tús an Quaestio, agus go minic sna himill, tugann sé tagairtí do áiteanna eile in ndéanann Scotus ceist ghaolmhar a phlé. Bhris sé suas an téacs i ranna agus chuir sé insteach i gló iodálach achoimrithe de ábhar na roinne a bhí díreach le teacht. Chuir sé téacsanna na Scrioptúir ar bhain Scotus úsáid astu i gló eile a bhí éagsúil ó chló an téacs féin. Ag deireadh eagrán na nAbairtí chuir sé insteach innéacs de phríomhábhair thráchtaireacht Scotuis ar na Sententiae agus innéacs (Indiculus) de na háibhair sna himleabhair a bhfuil baint acu le rúndiamhra an chreidimh agus leis na conspóidí a bhfuil trácht ag Scotus orthu.

${ }^{6}$ R.P.F. Joannis Duns Scoti Doctoris Subtilis, Ordinis Minorum, Quaestiones subtilissimae super libros Metaphysicorum Aristotelis [Venetiis 1497]. Epistola proemalis Mauritii. Mauritius Hibernicus Ordinis minorum Antonio Trombetae maximo eiusdem Ordinis, cum obseruantia salutem. Reprinted in Wadding [1639], Vol. IV.

${ }^{7}$ M. F. Morin in Dictionaire de philosophie et de théologie scholastiques (Migne, Paris 1856), col. 800 and repeated by Marie-Léon Patrem OFM, Tableau Synoptique de l'Histoire de tout l'Ordre Séraphique de 1208 à 1878 (Paris 1879) and by Ephrem Longpré in 1931, 'The Psychology of Duns Scotus and its Modernity' and 1932 'Psychologie scotiste et psychologie moderne'. Patrem (p. 130) writes as follows: Il est très remarquable, dit M.F. Morin, que dans H. Cavellus (Disp. de Anima opuscule qui sert de commentaire au De anima de Scot, Scoti Opera, t. iii) nous trouvions un essai complet de psychologie et même specialment d'ideologie. Dans le chapitre De evidentia, il y a des idées qui rappellent, en les devançant, celles de Descartes, notamment sur les songes, le sommeil, la certitude des sens; on dirait, en lisant cet auteur, que Descartes a pris dans ces prédésseurs une foule de théories particulières, sans les modifier, sinon par la place même qu'il leur donne dans la vaste organisation de la philosophie.

${ }^{8}$ C. Giblin, "Hugh McCaghwell, O.F.M., Archbishop of Armagh (+1626): Aspects of his Life"; originally published in Seanchas Ard Mbaca, xi, (1983-5), 259-90; reprinted in Dún Mbuire Killiney 1945-95. Léann agus
} 
I do not subscribe to this view, although possible, of a direct influence of McCaghwell upon Descartes as being very likely one, especially after an examination of the text.

In order to shed some light on what Cavellus has to say on certitude, I will examine what he has to say in at some of the questions presented in Disputatio III De Intellectu et Voluntate, namely, Sections 6 and 10 (pp. 635-641 in the Wadding edition of 1639)". Section 6 is entitled "On evidence and certitude", and in it Cavellus begins by stating that the intellect clearly and evidently knows its object when it clearly sees the connection between the subject and the predicate, either immediately through the terms themselves, or through a middle term, or by means of something better known (notius). He continues that evidence is something essential to, or at least a proper attribute of a clear act of the understanding. ${ }^{10}$ Evidence is threefold: moral; physical; and, metaphysical.

Moral evidence, he states, is when some eminent people, who are trustworthy, assert something which should be believed in accordance with the rules of prudence. The mysteries of faith obtain the highest level of this evidence because these are asserted by holy men who agree among themselves and are confirmed by many miracles. However, one can only speak of 'evidence' here in a qualified sense (secundum quid) because the revelation which it leads to, is, taken in itself, not evident but unclear (obscura). Physical evidence is when something is clearly known from physical principles, such as when there is great heat fire is known to be there. However, sometimes what appears physically evident is not always so, as is clear in the case of the sacrament of the Eucharist. Metaphysical evidence is when, by means of metaphysical principles, a thing is seen so clearly, or known, that it is impossible for things to be otherwise and it is impossible for something false to be concealed under this evidence.

Cavellus continues that some people are of the view that the evidence by which it is believed in far-off lands that 'Rome exists" ${ }^{11}$, is not moral evidence but physical evidence, since it is not any less evident that 'fire produces heat'. However, this is foolishly asserted (inepte dicitur), for it is impossible for fire not to produce heat, and if a miracle does not impede it, when fire is applied it necessarily produces heat. Again, without any miracle fire can reduce Rome to ashes and then for Rome not to exist. Moreover, it would be foolish to deny that the act by which Rome is known to exist, is human faith but to say instead that it is certain knowledge (scientificum). Those who do not see Rome believe that it exists only through human witnesses and not through any middle term or combination of terms.

In his answer (Dico primo) Cavellus states 'our intellect through its own powers evidently knows first principles and the conclusions which can be demonstrated from these, and the truths known through experience ... as Aristotle states (Metaphysics II,

Seanchas. Edited by Benignus Millett and Anthony Lynch. The Lilliput Press: Dublin 1995: pp. 63-94; p. 91.

${ }^{9}$ I wish to acknowledge the help that I received from the librarians of the Russell Library, St. Patrick's College, Maynooth, Penny Woods and Celia Kehoe who provided me with digital copies from the Wadding edition.

${ }^{10}$ Nota primo, tunc intellectum clare, et evidenter cognoscere obiectum, qunado tendit in illud instar oculi in lucem, vel colorem: ita vt manifeste videat connexionem praedicati cum subiecto, vel immediate per ipsos terminus, vel per medium notius. [p. 635a] ... Ex quibus patet euidentiam esse quid essentiale, vel saltem propriam passionem actus clari; et idem est de obscuritate respectu obscure. [p. 635b]

11 The origin of the example would seem to go back to Avicenna ('Mecca exists'), but the immediate historical antecedent was possibly F. Suarez, Tractatus de gratia pars tertia. De habitu justitiae sen gratiae gratum

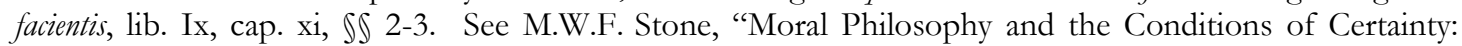
Descartes's Morale in Context", in R. Salles (ed.), Metaphysics, Soul and Ethics in Ancient Thought. Themes from the work of Richard Sorabji (Oxford: Clarendon Press, 2005) pp. 507-550; p. 524. Stone also notes that Suarez argues that moral certainty admits of degrees, e.g., high (maior) and low (minor) which is also followed here by Cavellus. 
text 1) "the first principles are known to all like the doorway in a house"". ${ }^{12}$ The knowledge of the conclusion depends upon the evidence of the principle together with a good inference depends and this is obtained naturally and evidently. Concerning what is known through experience, Cavellus states 'that which always or nearly always happens is a natural effect from a cause which is not free and this cause can only produce the effect determined by nature. Since, therefore, we always experience that fire heats, we infer that what it does has been imposed on it by nature; and thus this truth is known evidently. ${ }^{, 13}$

Cavellus continues: note that whenever the conclusion is known through experience, such as 'The moon is frequently eclipsed' (an example taken from the Posterior Analytics), this is recognised through a principle which is known in itself and which is the cause, namely, 'An opaque body when placed in front of a luminous body darkens the transparent medium'. This method is termed the analytical method (modus resolutivus) and it aims at a principle which is known in itself and which enables the conclusion to be demonstrated. ${ }^{14}$ Sometimes this resolution is not possible and the mind remains at the level of experiential knowledge only so that no cause is clear. The example given is 'a certain kind of plant is always spicy' which cannot be metaphysically evident since it does not exclude the possibility of an underlying falsity. ${ }^{15}$

A number of objections and responses now follow:

1. That by which the truth is represented, namely the species, is changeable since it comes from a changeable object. Again, the subject, namely the soul, is capable of error. Therefore, there is no evident or immutable truth in them. Cavellus replies: The species even if it is changeable in its being, represents in an unchanging way, just as a painted image, even though it can be destroyed, still unchangingly represents its prototype. As regards the changeability of the soul, he replies that it is not changeable as regards error, or regarding the information from terms, or the conclusions which can be drawn from them when the evidence is gained through a syllogistic inference.

2. A species can represent itself, as itself, or as an object; the latter is something which happens in dreams. Therefore, there is no evidence or certitude because if the species represents itself as an object this is incorrect and we are unable to discern when it is so or when it does so. Cavellus replies: it is not the species but the phantasm which represents itself as an object in dreams. However, he continues, it may be objected that the intellect can err because of the representation in the imagination, as is clear in dreams and delirium. For this reason cognition is not evident. His reply is that the intellect evidently knows that a lower power does not err regarding its object when the power is correctly used, unless the power is indisposed, and the intellect knows when it is indisposed, such as in the examples given. For, he says, I do not state that the aforementioned truths are always known without error because it can happen that in dreams the opposite of a first principle will appear; and yet it is not thus that this is not known per se.

\footnotetext{
12 Dico primo, intellectus noster euidenter suis viribus cognoscit prima principia, \& conclusiones ex eis demonstrabiles, \& veritates per experientiam notas. Ita Scot. 1. dist. 3. quest. 4. num. 5. contra Academicos, est Henricus in summ. art. 1. quaest. 2. Est Aristoteles 2. Metaph. Textu 1. Vbi ait prima principia esse omnibus nota sicut ianua in domo.

${ }^{13}$ De cognitis per experientiam, patet; quia quod semper, aut fere simper contingit fieri, \& non a causa libera, est effectus naturalis illius a quo fit, quia causa non libera, non potest in pluribus effectum producere, nisi ad quem natura sua determinata est: cum ergo semper experimur ignem calefacere, colligimus hoc esse illi a natura inditum; \& sic veritas haec euidenter cognoscitur. [p. 635b]

${ }^{14}$ The discussion would seem to refer to the Posterior Analytics and the ideal of analysing problems back to principles which are per se notum.

15 Aliquando vero sistitur in ipsa cognitione experimentali, ita vt non appareat vlla causa ipsius, verbi gratia: sed neutra experientia est euidens Metaphysice, quia non repugnat hic subesse falsum, vt dixi notabili 3 . \& et docet Scotus supra \$. Quandoque autem, num. 9.
} 
3. The third objection is that the species of the terms of the first principles depends upon the senses and these are often deceived; therefore so also is the assent of the intellect concerning first principles. Cavellus replies: if the intellect depends upon the services and functions of the senses in the acquiring of species, it does, however, make use of the senses through its own power when it composes and divides. So it is that an error of the senses does not impede the intellect, such as when, for example, sight when deceived judges that which is the whole to be less than that which is a part; but the intellect is not deceived on this account in stating that the whole is greater than the part.

Cavellus continues: I state that we have evident and certain information (notitia) concerning our acts; for example, that we are awake, that we are seeing, etc. and given that it is possible for there to be an illusion due to the object, or to the medium, or to an organ, this does not prevent us from knowing certainly and evidently that such acts are in us. ${ }^{16}$ In reply to Augustine's statement that 'no real truth is to be expected from the senses because they change unceasingly' Cavellus answers that indeed truth is not be had from the senses but rather from the intellect regarding their operations. An objection then followed based upon the sceptical argument of the apparently broken stick in water, to which Cavellus replies that the intellect clearly knows that sight is wrong here by means of the proposition 'no hard thing is broken by something which is soft and yielding to its touch'. Similarly, through the proposition 'when one quantity matches up to another they are equal', the same quantity can be applied to a seen quantity both near and far-off and so what is seen at a distance is not less than something near. Thus the intellect evidently judges by means of the species of the terms of the proposition, even if the species are taken from an erring sense.

He continues and notes that certainty is twofold:

a) the first which arises from the evidence of the object and from it reaches the highest point in understanding;

b) the second arises from the infallibility or veracity of the witness.

The latter if it derives from the testimony of God, is more certain in itself than the former because it is more perfect knowledge; the former, however, because it is clearer permits the subject in which it is to hesitate less concerning the truth.

He notes that certitude like evidence can be either moral, physical, or metaphysical. Thus, different levels of certainty can be assigned. For inasmuch as the act is more evident in natural things, the more certain it is. However, whereas faith may be the one thing most certain to the believer in this life because of the assent which is given, because of its lack of clarity, it does not exclude doubt from the point of view of the understanding. It is in this way, says Cavellus, that Aquinas is to be understood when he states that the assent of faith in itself is more certain that the act of knowledge, but not from our perspective (quoad nos). ${ }^{17}$

Section 10 is entitled: "Concerning opinion, faith, doubt, suspicion and apprehension - how do they differ?" Cavellus begins by stating that opinion is an act of the intellect which is deduced from intrinsic principles which do not evidently show what is the truth or falsity, such as this conclusion: 'Quantity is distinct from the size of a thing'. The intellect can assent or dissent from this. It differs from faith since this relies upon the testimony of the speaker even when this is divine faith, under which it is impossible for falsity to lie concealed

\footnotetext{
${ }^{16}$ Dico secundo, euidentiam, \& certam habemus notitiam de nostris actibus; verbi gratia, quod vigilamus, videmus, \&c. et esto illusio contingere posit, ratione obiecti, medij, vel organi, non tamen obstat quo minus certo, \& euidenter cognoscamus tales actus nobis inesse. Ita Scot. loco citato, num. 10. est Aristotelis 4. Metaph. [p. 636a]

17 Summa theologiae, 2a2ae, q. 4, a. 4.
} 
He divides opinion is into probable and improbable; the latter relies upon sufficient reasons so that following them is not judged to be acting imprudently; the former, on the contrary, because it relies upon many and more efficacious arguments, is a more probable opinion. ${ }^{18}$ However, Cavellus states in conscience it is sufficient to follow the probable (convincing), nor are you bound to follow the more probable (probabilior) nor the safer (tutior)'. ${ }^{19}$ He continues: it can happen that the less safe is the more probable, such as if there were many reasons excusing someone from making restitution, yet it would be safer (tutius) to make restitution. He concludes: 'you can follow the probable opinion of others against your own opinion, but then you are more properly following human faith.'

Human faith is assent on the account of the testimony of a man, and it barely differs from opinion because both rely upon an unclear fallible middle term (medio obscuro fallibili). In order to be able to follow this in conscience, the witnesses must be worthy of trust (fide digni); for the person who believes swiftly, is credulous. However, it differs from opinion in firmness, because it often excludes all apprehensiveness (formido), such as when I believe that the world existed before me, or that Rome exists. And thus faith is in between knowledge and opinion, because faith has apprehension with it, opinion does not.

Doubt or hesitation is an act by which it is judged that neither side can be definitively adhered to, because the intellect does not find a greater link between the terms (connexio extremorum) on this side rather than on the other. If no act is forthcoming, the doubt will be a negative one, (i.e., because there is an absence of sufficient evidence). It differs from apprehensiveness because this is a reflexive act, by means of which one judges that the opposite is perhaps more likely (verius) and does not exclude assent to one side. Thus, when there is apprehension regarding the opposite, it is right and permitted to do something, but not in the case of doubt.

If, however, one is doubtful because of intrinsic principles, one can follow the other side through extrinsic principles, for example, through the judgments of others. If it is legitimate to follow the opinion of others against ones own opinion, then so much more will it be permissible when you only doubt. Cavellus says that here again you are

\footnotetext{
${ }^{18}$ Diuiditur in probabilem, \& improbabilem; illa nititur ita sufficientibus rationibus, vt sequens eam non censeatur imprudenter agree; haec e contra, quo efficaciores, \& plures sunt rationes, eo probabilior est opinion. \& e contra. [p. 640b] See, M. Stone, "The Origins of Probabilism in Later Scholastic Moral Thought" in Recherches de Théologie et Philosophie Médiévales 67 (2000), pp. 114-157; p. 116n: 'Probabilism is a doctrine that states that in a case of moral perplexity an agent can act on 'either' horn of the dilemma provided that it can be shown that the opinion selected is 'probable', i.e., supported by authoritative arguments and judgments of reputable authorities. A further implication of the thesis is the view, so often the object of criticism, that in doing so an agent can reject the requirements of the more probable alternative and simply act on the probable opinion.' The doctrine seems to derive ultimately from derived from the endoxa of Aristotle in Topica I, i: Generally accepted opinions are those which commend themselves to all or to the majority of the wise - that is, to all of the wise or to the majority or to the most famous and distinguished of them.

${ }^{19}$ Diuiditur in probabilem et improbabilem; illa nititur ita sufficientibus rationibus, vt sequens eam non censeatur imprudenter agree; haec e contra, quo efficaciores, \& plures sunt rationes, eo probabilior est opinion. \& e contra. Sed in conscientia sufficit sequi probabilem nec teneris ad probabiliorem, neque ad tutiorem ... . [p. 640b]. It is interesting that Cavellus in subscribing to probabilism is following the views of some of the Jesuit theologians which he often likes to quote, namely Vasquez, Sancius, Azor and Suarez and departs from what will be the position of other Irish Franciscans at Louvain. The doctrine was not an uncontroversial one as M. Stone points out in "Moral Philosophy and the Conditions of Certainty: Descartes's Morale in Context", pp. 522-23: In 1655 the Louvain theologians condemned probabilism; and the followers of Jansenius adopted tutiorism or rigorism (a doctrine traced back to Innocent III 'in dubiis via est tutior eligenda') and rejected here also by Cavellus. In the eighteenth century, Franciscans tended to be probabiliorists, again rejected here by Cavellus.
} 
not required to follow the safer course; just as you are not when you follow someone else's opinion against your own.

Cavellus makes a further distinction between speculative and practical doubt. As an example of speculative doubt he gives the following: someone doubts whether a thing found among inherited things is theirs. An example of practical doubt follows: Is it permissible to keep such a thing? Cavellus states that it is permissible to act with a speculative but not with a practical doubt. Finally, Cavellus writes that suspicion is an act by which someone conjectures that someone else has attempted or done this or that, but it seems it does differ from opinion. So it is that it is probable or improbable, such as when an opinion is said to be unadvised when based upon a weak foundation.

\section{Conclusion}

To date Aodh Mac Aingil the poet is better known than Hugo Cavellus, philosopher and theologian, editor of Duns Scotus. For someone who began his university education in his early 30s Cavellus achieved a considerable amount in his twenty years or so as a teacher and writer. I have merely touched upon one theme here and there are many others still to be explored in the other disputationes on the substance of the soul, the corporeal powers of the soul and on the separated soul. For example in Disputatio II, Sect. 9 De visu, there are a number of dubia on the nature of light, colour and vision. From the initial study here something has emerged of Cavellus' own positions such as his support for the moral doctrine of probabilism.

A large number of Mac Aingil's former pupils went out to lecture in philosophy and theology throughout Europe. Thomas Fleming was a lecturer in philosophy in Aachen and in Cologne, Patrick Fleming who began as a lecturer in St Isodore's College in Rome, returned to Louvain, and then went on to Prague. Didacus Gray who was professor in Cologne; and the person who of them all was the most influential and ablest of them, Anthony O'Hickey was lecturer in Louvain, in Aachen, in Cologne and then eventually a professor in theology in St Isodore's College in Rome. Throughout the centuries which followed, whenever scholars read the works of Duns Scotus in Wadding's edition of the Opera Omnia, they also read Cavellus.

It is fair to say that a more balanced assessment of Cavellus' contribution is now becoming more common among scholars. Rather than merely supplying some helpful notes to reading Scotus, the importance of Cavellus's contribution to the Scotist school is becoming clearer as we begin to appreciate the context in which he worked. Scholars are beginning to recognize the importance of later Scholasticism, its concern with analysis and technical sophistication which as University philosophy formed the background for the popular presentation of similar themes in writers such as Descartes. Although Mac Aingil is not an easy author to approach at first but he is, unlike some others thinkers of the modern age, someone who more than repays time spent in his company. 